\title{
Can Stand Density and Stem Stratification Be Indicators of Aboveground Biomass in Woody Plant Recruitment in Savannah
}

\author{
Saran Traoré1,2,3*, Sébastien Ange Habih Nombré1,2, Issiaka Keïta1,2, Hassan Bismarck Nacro², \\ Brice Sinsin 4 \\ ${ }^{1}$ UFR/Sciences et Techniques, Université Nazi Boni, Bobo-Dioulasso, Burkina Faso \\ ${ }^{2}$ Laboratoire d'Etude et de Recherche en Fertilité de Sols, IDR, Université Nazi Boni, Bobo-Dioulasso, Burkina Faso \\ ${ }^{3}$ Laboratoire de Biologie et Ecologie Végétales, UFR, Sciences de la Vie et de la Terre, Université Joseph Ki-Zerbo, Ouagadougou, \\ Burkina Faso \\ ${ }^{4}$ Laboratoire d'Ecologie Appliquée, Faculté des Sciences Agronomiques, Université d'Abomey-Calavi, Cotonou, République du \\ Bénin \\ Email: *sarantraore_2003@yahoo.fr, *saran.traore@univ-bobo.bf
}

How to cite this paper: Traoré, S. Nombré, S. A. H., Keïta, I., Nacro, H. B., \& Sinsin, B. (2022). Can Stand Density and Stem Stratification Be Indicators of Aboveground Biomass in Woody Plant Recruitment in Savannah. Open Journal of Forestry, 12, 41-59.

https://doi.org/10.4236/ojf.2022.121003

Received: September 30, 2021

Accepted: November 21, 2021

Published: November 24, 2021

Copyright (c) 2022 by author(s) and Scientific Research Publishing Inc. This work is licensed under the Creative Commons Attribution International License (CC BY 4.0).

http://creativecommons.org/licenses/by/4.0/

\section{(c) (i) Open Access}

\begin{abstract}
Stem density and size stratification of woody species are informative of vegetation conditions and its physiognomy in savannah whereas their variation influence woody population functioning. Current study endeavoured to evaluate the stand density and size variability of woody species related to aboveground biomass in a Sudanian savannah. Total height, stem diameter at breast height $(\mathrm{dbh}) \geq 5 \mathrm{~cm}$ were measured in 30 plots of $50 \mathrm{~m} \times 20 \mathrm{~m}$ laid in respect to vegetation type as bowal, shrubland and woodland. Species diversity, stem density, height and basal area were calculated and compared across sites and variation in stem dbh classes evaluated. Total aboveground biomass was estimated and thereafter linear relationships were established between stand density and aboveground biomass, and basal area. Results revealed three different sites with an overall 58 species identified through vegetation type including liana species ( 4 stems in bowal) with 18 genera and 42 families. Fabaceae Combretaceae, Anacardiaceae and Rubiaceae were dominant families. Small sized trees represented $72 \%$ of total stem density considered in structure with significant higher basal area, while large sized trees as $28 \%$ were scarcely distributed. More than $70 \%$ variation in biomass was due to stem density and basal area with a dominance of small trees. In conclusion increase size in tree community indicated increase in accumulated aboveground biomass as positive regeneration features. But, change in vegetation structure strongly influence negatively species ability to grow from lower to upper size class and later on, disrupt ecosystem functioning. Plant stem den-
\end{abstract}


sity and stratification could be considered as indicators of aboveground biomass fluctuating in regeneration monitoring.

\section{Keywords}

Aboveground Biomass, Biodiversity Conservation, Plant Regeneration, Stem Structure, Vegetation Type

\section{Introduction}

Woody plant regeneration and conservation as well as restoration and suitable management of ecosystems are permanently major challenges for ecologists, researchers, other plant scientists and for environmental decision makers seeking continuous provision of multiple ecosystem goods and services (Lorenz \& Lal, 2010; Manaye et al., 2021). The challenges are exacerbated today due to climate change, demographic growth, agricultural activities expansion and galloping urbanization that jeopardize the local biodiversity stability and resilience and vegetation productivity (Rakotomavo et al., 2018). In the light of challenges for the sake of pursuing sustainable management and suitable conservation of lands and biodiversity (ecosystem goods and services), a many management practices as controlled livestock grazing and/or prescribed fire (early or late), protected area establishment, agroforestry systems, silvicultural thinning have been implemented in tropical and subtropical ecosystems (Sawadogo et al., 2005; Higgins et al., 2007; Lorenz \& Lal, 2010; Murphy et al., 2015; Adjahossou et al., 2017; Ganamé et al., 2019). For instance, in arid and sub-arid regions protected areas are promoted as reserve forests or state forests (Higgins et al., 2007) through marking the boundaries of some natural wooded spaces, parklands on smallholdings and fallows or cultivated lands in many parts of the country as national strategy. All these protected areas with or without management tools and, considered as favourable habitats endeavour to promote biodiversity conservation, threatened species regeneration and, degraded land rehabilitation (Sawadogo et al., 2005; Lorenz \& Lal, 2010; Murphy et al., 2015). At the same time these protected spaces are experiencing heavy anthropogenic pressure worldwide such as the illegal harvest of woody species and forest degradation that induce and maintain spatial heterogeneity as a discontinuity in vegetation layer (canopy cover) in place and the distributions of size-classes. Yet, to be effective and efficient, any strategy of biodiversity conservation must solve as possible as, the problems of erosion which apparently occurs at a raised rate. Otherwise, all the operations undertaken become useless due to misfit practices and/tools. Previous researches have reported that variability in species diversity induce important variability in ecosystem functioning allocated to the density and spatial distribution of stem sizes (ontogenic stages), tree biomass productivity within or inter plant community (Hooper et al., 2005; Lorenz \& Lal, 2010; Matula et al., 2015). Biomass production at any given time and in any vegetation is considered 
to be a key guide of plant species capability to incorporate carbon and nutrients to be later used (Weiber \& Grulke, 1995). As such, it plays an important role in plant growth and establishment. By contrast, variability in plant species diversity may also result from the favoured establishment of some abundant individuals (complementarity actions or compensatory) or the impediment recruitment of others (antagonism) through the effects of vegetation types and land cover degree (Lorenz \& Lal, 2010; Traoré et al., 2015).

While stand density and stem size distribution of woody species (conspecific) in a community can vary in growth rate due to unbalance disturbance intensity and other stress (Attua et al., 2017) and to the degree of physical injuries on aerial systems, the functioning of woody plant can also be influenced in terms of aboveground biomass production of each species during regeneration process. Importantly, AGB producing might be an attribute of good or weak growth performance but many species in turn exhibit different physiological and/or morphological responses to vegetation conditions. For instance, Coomes \& Allen (2007) argued that small trees were less competitive in large canopy vicinity and grew slowly and weakly as a consequence, while larger trees were not affected by canopy cover. The obvious conditions include woodland, shrubland and bowal with different degree of canopy. Reports support that the coexistence of several species in abundance may significantly be complementary for area characteristics (Holmgren et al., 2004; Hooper et al., 2005) whereas some species are the mark of particular areas (e.g. desert, rain forest, mountain...). In consequence, the way and rate at which plant stem is extended depend firstly on each species properties and, secondly on species response to the vegetation conditions in which it grows under interaction between different plant strata and other factors (biotic and abiotic) (Sawadogo et al., 2005; Coomes \& Allen, 2007). Each plant species elaborate new tissues as gained biomass during its (re)growth for its stem diameter and height (Weiber \& Grulke, 1995).

Community structure and regeneration statu are frequently evaluated by the pattern of size classes (or horizontal distribution) measured as diameter at breast height (dbh) (Holl \& Zahawi, 2014) as important features in ecosystem properties. Therefore, evaluating stand density and trunk size stratification relating to aboveground biomass can also help to understand the functioning of woody populations in savannah ecosystem in accordance with their physiognomy. The current work has been undertaken to highlight linkage between woody stand conditions and its functioning. It may positively contribute to understand stem size attributes on ecological processes and then help in designing and achieving future research leading to sustainable management and strategy development. Recent studies at relative natural savanna have focused on particular woody species (biodiversity and biomass) with purpose to develop allometric equations (Mbow et al., 2014; Dayamba et al., 2016; Balima et al., 2019; Damena \& Teshome, 2019) or quantify carbon budget and/or released included only individuals with $\mathrm{dbh}>$ or $\geq 10 \mathrm{~cm}$ (large trunks). In contrast, studies based on entire woody communities (combination of many populations) growing in the same 
environmental conditions considering stem stratification as clue of plant recruitment are scarce (Gebrewahid et al., 2018) in arid and sub-arid ecosystems.

This investigation generally aimed at assessing the stand density, stem size stratification as bio-estimators of living aboveground biomass (AGB) of woody plants during (re)growth process. As for the specific objectives, we explored 1) the species diversity of woody communities, 2) we assessed stem horizontal structure as the evaluation of recruitment degree of woody plant, and 3) we quantified AGB relating to stand density and stem diameter patterns as the magnitude of primary productivity. We assume that stem size be indicator of increase aboveground biomass as positive features of small sized tree recruitment to large sized trees.

\section{Material and Methods}

\subsection{Description of Study Site}

The present study was carried out in the state forest of Dindéresso. This forest is located in the North-West of the city of Bobo-Dioulasso, Western Burkina Faso at an altitude of $300 \mathrm{~m}$ at sea level, between $11^{\circ} 11^{\prime}-11^{\circ} 18^{\prime} \mathrm{N}$ latitude and $4^{\circ} 10^{\prime}$ $4^{\circ} 30^{\prime} \mathrm{W}$ longitude (Figure 1).

Local climate is characterized by a dry season and a rainy season alternating. Data recorded by local meteorology department from 1998 to 2018 showed that

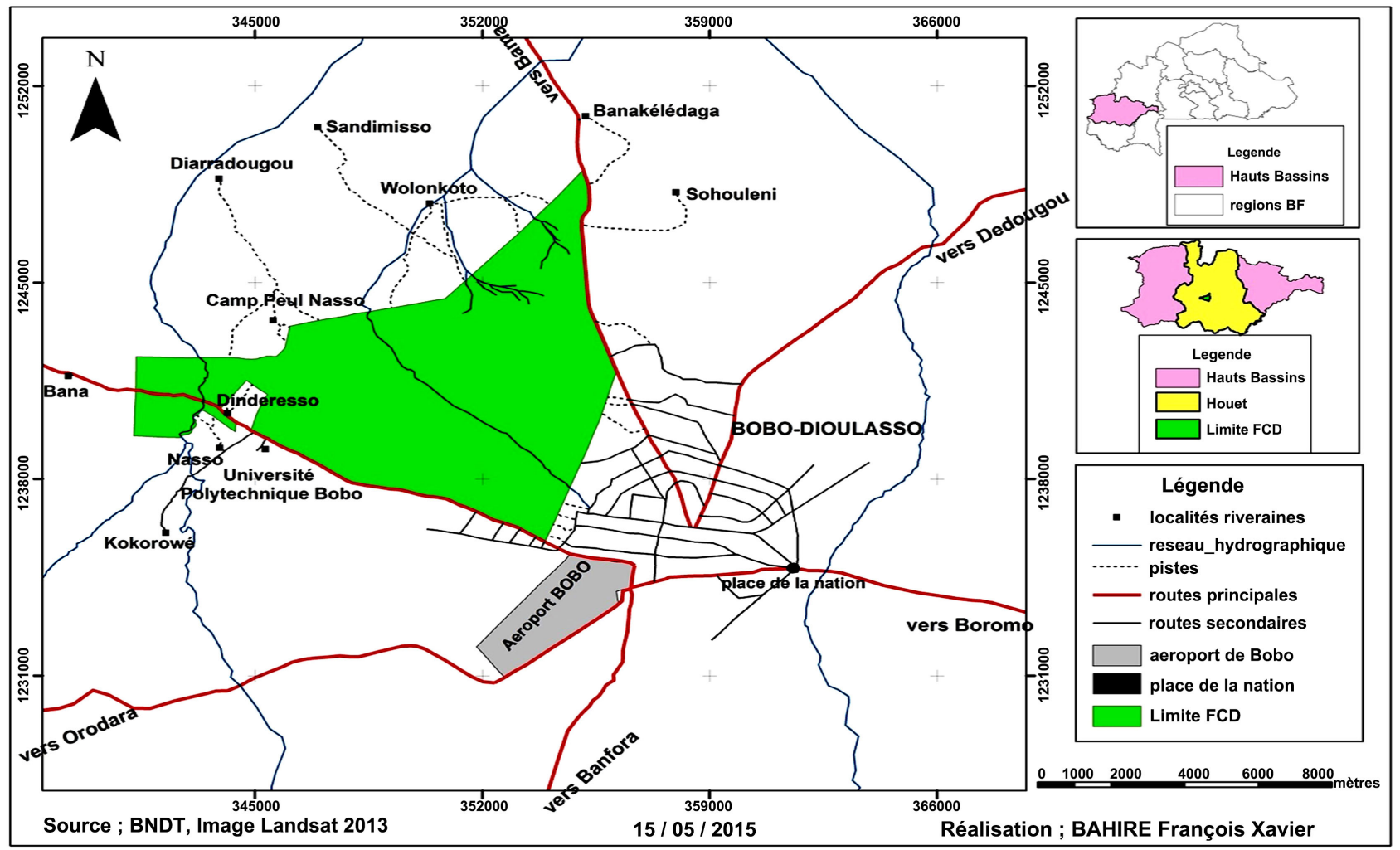

Figure 1. The geographical location of study site, Dindéresso state forest, Burkina Faso (Source: Bahiré, 2016). 
rainy season lasts from April to October (7 months) with an average rainfall of $1038.68 \pm 174.31 \mathrm{~mm}$ per annum while a total rainfall of $1320 \mathrm{~mm}$ was recorded in 2018. Dry season lasts from November to March (4 months) and January and April are the coldest $\left(15.89^{\circ} \mathrm{C}\right)$ and hottest $\left(40.42^{\circ} \mathrm{C}\right)$ months respectively.

Soils are rocky and are identified as Lixisols according to the FAO classification system (Driessen et al., 2001). They are slightly deep $(>85 \mathrm{~cm})$ and poor (Nitrogen $=0.058 \%$; phosphorus $=1.77 \mathrm{ppm}$ and carbon $=0.33 \%)$ with low amounts of organic matter.

Local vegetation is a humid savannah of the Sudanian regional centre of endemism (White, 1983). This vegetation is a mosaic patch constituted of gallery forest, clear bush savannah, wooded and opened savannahs, dense wooded savannah, with annual and/or perennial grasses (Fontes \& Guinko, 1995). Wooded savannah was interrupted by shrub (or bush) savannah where species such as Burkea africana, Combretum sp, Detarium microcarpum, Grewia mollis, Terminalia sp and Vitellaria paradoxa dominated tree stratum. Despite the fact that this forest is increasingly threatened because of increasing density of local resident generating a great consumption of natural resources and a need of open space for multiple uses it remained an appropriate environment for ecological investigations as the present study.

\subsection{Experimental Design and Woody Plant Sampling}

During the midst of rainy season in 2018, the study area was explored using the official road delimited by Forest Department and the network of trails drawn during illegal livestock grazing. Survey was conducted from August to December 2018 using vegetation community characteristics and scientific criteria of Arbonnier (2000). According to this author wooded land (or opened savannah) is characterized by separated trees and the abundant individuals of species as Anogeissus leiocarpus (DC.) Guill. \& Perr., Combretum sp, Detarium microcarpum Guill. \& Perr., Isoberlinia doka Craib \& Stapf., Pterocarpus erinaceus Pair., Terminalia sp and Vitellaria paradoxa var. paradoxa Gaertn f. Shrubland is dominated by Acacia macrostachya Reichenb. ex DC, Combretum sp, Lannea sp, Gardenia sp, Maranthes polyandra (Benth.) Prance, Crossopteryx febrifuga (Afzel. ex G. Don) Benth, Sarcostemma viminale (L.) R.Br between 1 and $2 \mathrm{~m}$ above soil surface and annual grass layer as Loudetia togoensis (Pilg.) C. E. Hubb., and Pennisetum pedicellatum. Bowal also refers to a shrubland but characterized by the combination of an annual grass layer, some scattered shrub species on bare soil surface and crusted soils that are practically inappropriate productively. Abundant mushroom-shaped mounds of termite Cubitermes spp (humivorous) were found at $99 \mathrm{ha}^{-1}$ (Kéita, 2019). We randomly set 3 compact transect lines up in area based on a preliminary identification as old-growth (or relic) vegetation where no plantation and conservation techniques exist. This part of forest was not affected by wild fire disturbance. Distance between transect lines is over $1 \mathrm{~km}$. The first transect was laid out in shrubland, the second in woodland and the third one in bowal. A total of 10 contiguous rectangular plots 
of $50 \mathrm{~m} \times 20 \mathrm{~m}$ were delimited along each transect line hanging out $500 \mathrm{~m}$ long and $20 \mathrm{~m}$ wide covering 1 ha of area as blocks (Krebs, 1972).

In each delimited plot, all the vascular plants of which the diameter measured at breast height, or $130 \mathrm{~cm}$ above soil surface was equal or greater than $5 \mathrm{~cm}$ $(\mathrm{dbh} \geq 5 \mathrm{~cm})$ and stem height greater than $130 \mathrm{~cm}$, were systematically recorded per species. Liana species was recorded for complete species assessment only but not included in structural analysis as well as in biomass calculation because of the lack of wood specific-density for savanna vegetation. The samples of unidentified species were collected for being later identified. Scientific nomenclature was later updated following IPNI (2021, July 29) \& IUCN (2021, July 29). Circumference at breast height (Cbh) and, stem total height were measured for single individuals. In case of multi-stemmed plants, the circumference and height of each stem satisfying the criterion of $\mathrm{dbh} \geq 5 \mathrm{~cm}$ were also measured as the main trunks of plant from the base to the top as Pearson et al. (2005) and Matula et al. (2015).

\subsection{Data Handling and Statistical Analysis}

Each transect with 10 plots was considered as study block (Krebs, 1972) and the formula of Bray-Curtis index defined in Equation (1) (Kindt \& Coe, 2005) was performed to assess ecological similarity or dissimilarity between vegetation type. This index of similarity allows assessing species diversity and abundance as single statistic and its value ranges from 0 (similarity for all species) to 1 (no species in common). This is because habitat heterogeneity may lead to an increasing or scarcity in species diversity (Kadéba et al., 2014) and (Traoré et al., 2015).

Index of Bray-Curtis

$$
B C_{i j}=1-\frac{2 C_{i j}}{S_{i}+S_{j}}
$$

where: $i \& j$ are vegetation type; $S_{i} \& S_{j}$ refer to total species number counted for vegetation type $i \& j$ respectively; $C_{i j}$ is the sum of only the minor counts for each species found in both vegetation type.

Species richness as the total number of plant species was determined based on observed and estimated species number. Estimated species richness was graphically obtained with the rarefaction curves of species-cumulative stem number using EstimateS 9.10 package (Colwel, 2013). Species richness was later compared between vegetation types during sampling period in 2018.

Community structure was described for each vegetation type as average stand density and basal area at breast height (dbh). Histogram was drawn to highlight the distribution of dbh classes as the function of stem density in spatial distribution (horizontal distribution). Beyond total height, the distribution of stems in dbh classes may be an indicator of recruitment constituents and a predicate of the different successional stages in seedling to saplings, and saplings to adult tree transition or degree of disturbance. For this purpose, we considered stems of $5 \leq$ 
$\mathrm{dbh} \leq 10 \mathrm{~cm}$ as small-sized and those of $\mathrm{dbh}>10 \mathrm{~cm}$ as large-sized trees (Kuma \& Shibru, 2015). Within large stems, other groups were discriminated as $10<$ $\mathrm{dbh} \leq 15 \mathrm{~cm} ; 15<\mathrm{dbh} \leq 20 \mathrm{~cm}$ and, $\mathrm{dbh}>20 \mathrm{~cm}$ to explore the contribution of each class to density distribution and biomass group.

Prior to assessing fresh biomass, the total AGB of living plants was indirectly estimated. Allometric equation (Equation (2)) for non-destructive woody plant biomass in tropical dry forests and savannah with similar environmental conditions of our sampling communities was used regarding Mbow et al. (2014); Chave et al. (2014) \& Dayamba et al. (2016)

$$
A B=0.0673\left(\rho D^{2} H\right)^{0.976}
$$

with $\rho=$ wood density $\left(\mathrm{g} \cdot \mathrm{cm}^{-3}\right), D=\mathrm{dbh}(\mathrm{cm})$ and $H=$ height $(\mathrm{m})$.

Relationship was established between successional groups referring to stem dbh classes as recruited categories. The values of wood density for each species were obtained from the global wood density database (Chave et al., 2009, 2014; Zanne et al., 2009) available from the Dryad data repository (http://datadryad.org/). The average value wood density was calculated and used when different values of wood density exist for the same species taken in the same climatic conditions. In case specific-species wood density was unavailable, we calculated the average value of wood density of plant genus or family and afterwards integrated this value. Finally, the values of wood density, stem $\mathrm{dbh}$ and total height $\mathrm{H}$ were computed. AGB was firstly calculated for each stem, summed for each species and then pooled for each plot. The estimated total AGB of tree community was obtained as the sum of AGB of pooled species per plot in tons per hectare as AGB density $\left(\mathrm{t} \cdot \mathrm{ha}^{-1}\right)$ and compared through the three vegetation types. Total AGB of living plant was considered as a measure of the ability of each species population to elaborate new tissues and organs for regenerating or repairing after physical injuries.

The one-way analysis of variance (ANOVA) was performed to assess the influence of vegetation type on total stem density and basal area at breast height for the average values among vegetation patches. Total basal area was previously $\log (x+1)$ transformed to meet homogeneous variance. Multiple comparisons were then performed with Tukey's HSD test for homogeneous subsets for averages that exhibited significant difference ( $p$-value $<0.05)$. Non-parametric Kruskall Wallis $\mathrm{H}$ test (Zar, 1999) was applied to data on AGB because of unequal variance distribution. In addition, relationship was established using linear regressions for assessing any variation in $\mathrm{AGB}$ as a function of stem density and basal area at breast height for small and large stem. Statistical analysis were carried out at $p$-value $<0.05$ using IBM SPSS version 20 package for Windows.

\section{Results}

\subsection{Species Diversity and Composition of Plant Community}

The calculated value of Bray-Curtis's index of similarity was under value 1 . This 
index value showed the low degree of dissimilarity between bowal and woodland $\left(B C_{i j}=0.19\right)$ and, between bowal and shrubland $\left(B C_{i j}=0.20\right)$. But between wood- and shrubland $\left(B C_{i j}=0.46\right)$ this index value tended towards 1 indicating that these two vegetation types were different from each other in term of species diversity and abundance.

Total species richness included in total 58 species counted from overall data recorded for a total 1557 plant individuals considered on the 3 ha of area surveyed (Table 1). Out of the total identified species 30,35 and 45 species were respectively noted on bowal (or 51.72\%), shrubland (or 64.74\%) and woodland

Table 1. Complete list of woody plant species and their densities (individuals in 10 plots of $50 \mathrm{~m} \times 20 \mathrm{~m}$ ) recorded on bowal, shrubland and woodland in Dindéresso forest in 2018.

\begin{tabular}{|c|c|c|c|c|}
\hline \multirow{2}{*}{ Species name } & \multirow{2}{*}{ Family } & \multicolumn{3}{|c|}{ Study plot location } \\
\hline & & Bowal & Shrubland & Woodland \\
\hline Acacia macrostachya Reichenb. ex DC & Mimosaceae & 43 & - & 1 \\
\hline Acacia polyacantha Willd. & Mimosaceae & - & 15 & 2 \\
\hline Afzelia africana Sm. ex Pers. & Caesalpiniaceae & - & - & 1 \\
\hline Albizia lebbeck (L.) Benth. & Mimosaceae & - & - & 1 \\
\hline Annona senegalensis Pers. & Annonaceae & 2 & 6 & 8 \\
\hline Anogeissus leiocarpa Guill. \& Perr. & Combretaceae & - & - & 114 \\
\hline Bombax costatum Pellegr. \& Vuillet & Bombacaceae & 4 & - & - \\
\hline Bridelia ferruginea Benth & Euphorbiaceae & - & 9 & - \\
\hline Burkea africana Hook. & Caesalpiniaceae & 3 & 37 & 7 \\
\hline Cassia arereh Delile & Fabaceae & - & - & 8 \\
\hline Cassia sieberiana DC. & Fabaceae & 44 & 2 & 1 \\
\hline Celtis integrifolia Lam. & Ulmaceae & 2 & - & 3 \\
\hline Combretum collinum Fresen. & Combretaceae & - & - & 4 \\
\hline Combretum fragrans $\mathrm{F}$. Hoffm. & Combretaceae & - & 7 & 3 \\
\hline Combretum glutinosum Guill. \& Perr. & Combretaceae & 21 & 2 & 1 \\
\hline Combretum lecardii Engl. \& Diels & Combretaceae & - & 8 & - \\
\hline Combretum micranthum G. Don & Combretaceae & - & 5 & - \\
\hline Combretum molle R. Br ex G. Don & Combretaceae & - & 2 & 2 \\
\hline Combretum nigricans Lepr. ex Guill \& Perr. & Combretaceae & 3 & 16 & 8 \\
\hline Combretum paniculatum Vent. & Combretaceae & - & 2 & - \\
\hline Crossopteryx febrifuga Benth. & Rubiaceae & 1 & 6 & 1 \\
\hline Daniellia oliveri (Rolfe) Hutch. et Dalz. & Fabaceae & 3 & 15 & 53 \\
\hline Detarium microcarpum Guill. \& Perr. & Caesalpiniaceae & 110 & 30 & 1 \\
\hline Dichrostachys cinerea (L.) Wight \& Arn. & Fabaceae & - & - & 1 \\
\hline Diospyros mespiliformis Hochst. ex A. DC. & Ebenaceae & 4 & 1 & 9 \\
\hline Entada africana Guill. \& Perr. & Fabaceae & 22 & - & 9 \\
\hline
\end{tabular}




\section{Continued}

Ficus cordata Ridl.

Ficus sycomorus $\mathrm{L}$.

Gardenia aqualla Stapf \& Hutch.

Guiera senegalensis Lam.

Hexalobus monopetalus Engl. \& Diels

Hymenocardia acida Tul.

Isoberlinia doka Craib \& Stapf

Khaya senegalensis A. Juss.

Lannea acida A. Rich., Guill. \& Perr.

Lannea microcarpa Engl. \& K. Krause

Lannea velutina A. Rich., Guill. \& Perr.

Maranthes polyandra (Benth.) Prance

Opilia celtidifolia Endl. S. Walp.

Parinari curatellifolia Planch. ex Benth.

Parkia biglobosa Benth.

Pericopsis laxiflora (Benth. ex Baker) Meeuwen

Piliostigma thonningii (Schumach.) Milne-Redh.

Prosopis africana Taub.

Pteleopsis suberosa Engl. \& Diels

Pterocarpus erinaceus Poir.

Saba senegalensis (A. DC.) Pichon

Sarcocephalus latifolius (Sm.) E.A. Bruce

Sclerocarya birrea Hochst.

Strychnos innocua Delile

Strychnos spinosa Lam.

Terminalia avicennioides Guill. \& Perr.

Terminalia laxiflora Engl.

Terminalia macroptera Guill. \& Perr.

Terminalia mollis M. A. Lawson

Vitellaria paradoxa var. paradoxa C. F. Gaertn.

Vitex simplicifolia Oliv.

Xeroderris stuhlmannii (Taub.) Mendonça \& E.P. Sousa
Moraceae 13

Moraceae

Rubiaceae

Combretaceae

Annonaceae

Euphorbiaceae

Fabaceae

Meliaceae

Anacardiaceae

Anacardiaceae

Anacardiaceae

Chrysobalanaceae

Opiliaceae

Chrysobalanaceae

Fabaceae

Fabaceae

Fabaceae

Fabaceae

Combretaceae

Fabaceae

Apocynaceae

Rubiaceae

Anacardiaceae

Loganiaceae

Loganiaceae

Combretaceae

Combretaceae

Combretaceae

Combretaceae

Sapotaceae

Lamiaceae

Fabaceae

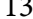

15

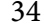

4

5
1

3

2

2

10

-

11

9

1

4

3

8

4

1

1

15

4

3

2

12

4

25

28

19

96

1

440

620

497

(or 77.59\%). The three vegetation patches shared with each other 17 species. Six species were common between bowal and woodland, 11 species between shrubland and woodland and only 1 species Terminalia mollis M. A. Law. was found on both bowal and shrubland. Eleven species were recorded on woodland solely 
while 6 were identified on each of bowal and shrubland respectively. The level at which the recorded species accumulated with the number of woody plants relating to the different vegetation type was summarized and showed in Figure 2. Species richness increased as a function of stem number in each vegetation type. Rarefaction curve tended toward a flatness for shrubland and almost for woodland where species number became constant and while stem number is still increasing (Figure 2). For instance, when samples are reduced to the value of $\mathrm{N}=$ 440 stems observed in bowal, species richness with stem number in woodland exceeded those recorded in both bowal and shrubland (Figure 2, Table 2). Bowal had the lowest species richness and shrubland intermediate species richness.

At floristic scale, the total species included 18 genera and 42 families (Table 1). Among recorded families, 13, 13 and 14 were noted on bowal, shrubland and woodland respectively. Fabaceae was the dominant family with 18 species followed by Combretaceae (15 species), Anacardiaceae (4 species) and Rubiaceae ( 3 species).

Twenty-six genera were present on bowal, 25 on shrubland and 36 genera on woodland. Bowal and woodland did not shelter any species of Combretaceae family.

\subsection{Community Structure of Woody Plants}

Stand structure was analysed by excluding liana species as Saba senegalensis (A. DC) Pichon (4 stems in bowal) leading to use 1553 as total stem number to follow up. All stems encountered and measured in 3 ha of area constituted a total density of 517.67 stems $\cdot h^{-1}$. Total stem density ranged from 436 in bowal to 620 stems $\cdot \mathrm{ha}^{-1}$ in shrubland as showed in Table 2 . The density of small and large stems follows the same trend.

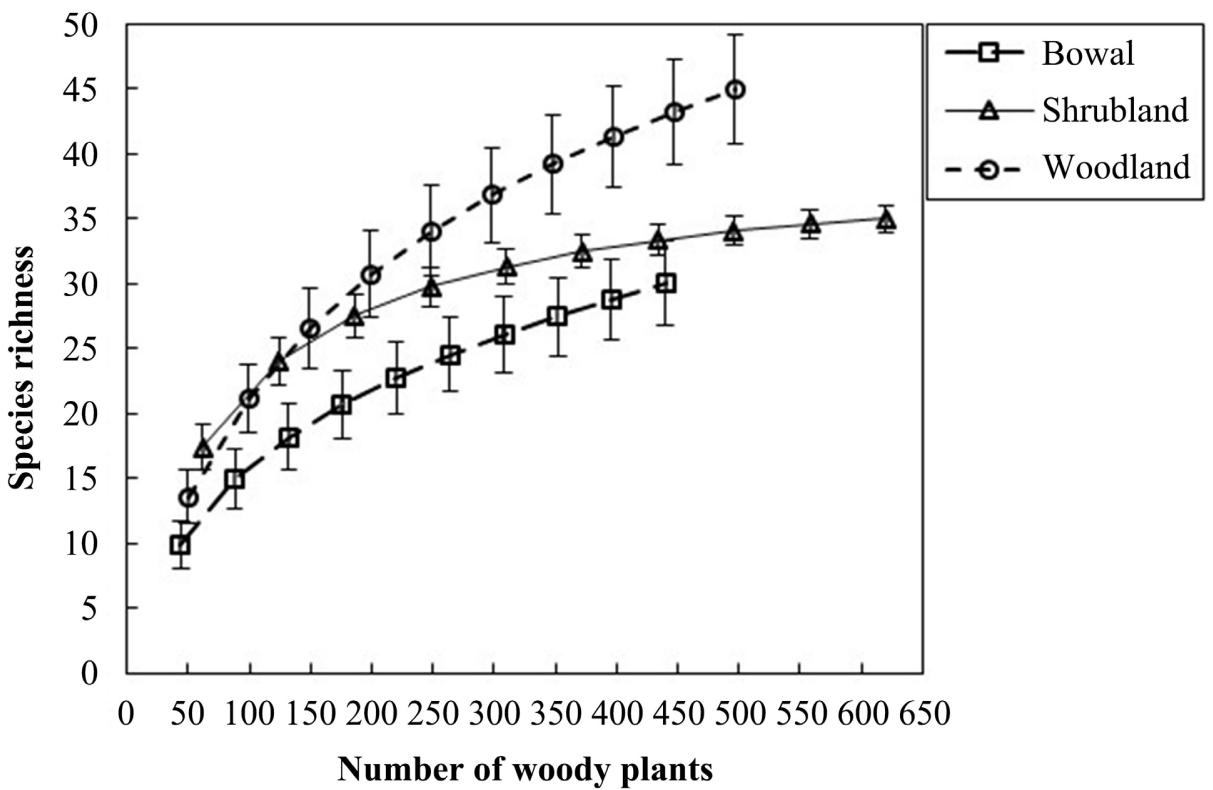

Figure 2. Curves of species-plant number accumulation (with standard deviation bar) for all sampled trees $\mathrm{dbh} \geq 5 \mathrm{~cm}$ in each vegetation type in forest in 2018 . 
Table 2. Plot-level variation in estimated species richness, average values ( \pm standard deviation) of stem density, height, basal area at breast height and biomass of woody plant recorded in 2018 per vegetation type.

\begin{tabular}{|c|c|c|c|c|c|c|}
\hline \multicolumn{7}{|c|}{ Study plot location } \\
\hline Variables & Bowal & Shrubland & Woodland & Total & $\mathrm{F}$ & $P$ value \\
\hline Number of plots & 10 & 10 & 10 & 30 & & \\
\hline Rarefied stem number & 440 & 434 & 447 & & & \\
\hline Rarefied species richness & 30 & 33 & 40 & & & \\
\hline Density of trees (stems $\cdot \mathrm{ha}^{-1}$ ) & $436.00 \pm 235.10$ & $620.00 \pm 175.94$ & $497.00 \pm 180.62$ & 2.22 & 0.048 & \\
\hline Small trees density $\left(\right.$ stems $\cdot \mathrm{ha}^{-1}$ ) & 336 & 432 & 351 & 1119 & & \\
\hline Large trees $\left(\right.$ stems $\left.\cdot \mathrm{ha}^{-1}\right)$ & 100 & 188 & 146 & 434 & & \\
\hline Height (m) & $4.52 \pm 0.78 a$ & $5.24 \pm 0.40 a b$ & $5.43 \pm 0.73 b$ & & 5.34 & 0.011 \\
\hline Maximum height (m) & 5.83 & 6.00 & 6.58 & 6.58 & & \\
\hline Maximum dbh $(\mathrm{cm})$ & 41.38 & 49.66 & 46.79 & & & \\
\hline Basal area at breast height $\left(\mathrm{m}^{2} \cdot \mathrm{ha}^{-1}\right)$ & $3.03 \pm 2.06 a$ & $5.36 \pm 0.97 b$ & $4.72 \pm 2.69 a b$ & & 4.16 & 0.027 \\
\hline Aboveground biomass $\left(\mathrm{t} \cdot \mathrm{ha}^{-1}\right)$ & $7.59 \pm 6.27$ & $15.99 \pm 3.17$ & $18.53 \pm 12.81$ & & & \\
\hline Small trees AGB $\left(\mathrm{t} \cdot \mathrm{ha}^{-1}\right)$ & 3.01 & 4.72 & 3.49 & & & \\
\hline Large trees AGB $\left(\mathrm{t} \mathrm{ha}^{-1}\right)$ & 4.59 & 11.27 & 15.04 & & & \\
\hline
\end{tabular}

Average values with the same letter(s) across same lines for each vegetation type are not significantly different (at $p$-value $>0.05$ ) according to Tukey's HSD test.

At species level, 10 species as Anogeissus leiocarpus (DC.) Guill. \& Perr., Burkea africana Hook f., Daniellia oliveri (Rolfe) Hutch. \& Dalz, Detarium microcarpum Guill. \& Perr., Isoberlinia doka Craib \& Stapf., Parinari curatellifolia Planch. ex Benth., Pteleopsis suberosa Engl. \& Diels, Terminalia avicennioides Guill. \& Perr., Terminalia laxiflora Engl., T. macroptera Guill. \& Perr., Vitellaria paradoxa var. paradoxa Gaertn. contributed to increase stem density (Table 1).

In contrast, woodland exhibited taller individuals with the highest average value of stem height $(5.43 \pm 0.73 \mathrm{~m})$ and maximum stem height value $(6.58 \mathrm{~m})$ (Table 2).

The overall difference observed in stem density tended to be significant $(\mathrm{F}=$ $2.22, p$-value $=0.048)$ as the influence of vegetation type (Table 2 ) while difference in stem height was strongly pronounced between woodland and bowal solely (Anova, $\mathrm{F}=5.34, p$-value $=0.011$ ).

Only the average value of Log stem basal area at dbh was statistically greater for shrubland than bowal (Anova, $\mathrm{F}=4.16, p$-value $=0.027$ ) in multiple comparison of average values. Woodland showed an intermediate average value. In the term of homogeneous areas for stem height and basal area at dbh, the vegetation of bowal was particularly different and specific while those of shrubland and woodland were similar.

Although the total density of stems was uniformly distributed, the individuals of large sized $\mathrm{dbh}>10 \mathrm{~cm}$ were almost sparce and depleted in all the sampled area of 3 ha and represented $27.95 \%$ of total stem. This group was dominated by 
stems of classes [10 - 15] and [15 - 20] across the three areas (Figure 3) Small sized stems (dbh class of [5 - 10]) were prevalent with the highest total density of $1119 \mathrm{ha}^{-1}$ making up $72.05 \%$ of total stem density.

In return, the average value of stem basal area at breast height ( $\mathrm{dbh}$ ) ranged from $4.72 \pm 2.69 \mathrm{~m}^{2} \cdot \mathrm{ha}^{-1}$ for woodland to $3.03 \pm 2.06 \mathrm{~m}^{2} \cdot \mathrm{ha}^{-1}$ for bowal respectively (Table 2).

The higher values of stem basal area $\left(5.36 \pm 0.97 \mathrm{~m}^{2} \cdot \mathrm{ha}^{-1}\right)$ and maximum value of stem dbh $(49.66 \mathrm{~cm})$ were recorded in shrubland and lower values on bowal according to Table 2 .

\subsection{Relationship between Stand and Aboveground Biomass}

The total net primary productivity of woody plants as living AGB linearly increased from bowal $\left(\mathrm{AGB}=7.59 \mathrm{t} \cdot \mathrm{ha}^{-1}\right.$ ) to woodland with the highest value $\left(\mathrm{AGB}=18.53 \mathrm{t} \cdot \mathrm{ha}^{-1}\right)($ Table 2$)$. The overall AGB was statistically different (Kruskall Wallis $\mathrm{H}=6.79, p$-value $=0.034$ ) across vegetation type. These values fluctuated across dbh classes and were remarkably influenced by stem density in bowal exceptionally.

Linear regression analysis were performed on the one hand between stem density and biomass, and on the other hand between stem basal area at breast height. Results revealed that variation in AGB was highly positive and significant ( $p$-value $<0.05)$ for small sized stem density and basal area and for large sized stem basal area in woodland only (Table 3 ). More than $67 \%$ of variation observed in AGB in bowal ( $p$-value $<0.0001)$ and woodland $(p$-value $=0.004)$ were due to the great density of small stem. Solely shrubland in where $91 \%$ and $76.3 \%$ variation in AGB were remarkably caused by higher density ( $p$-value $<0.001$ ) of small stem and by basal area of large stems $(p$-value $=0.001)$. In woodland, almost

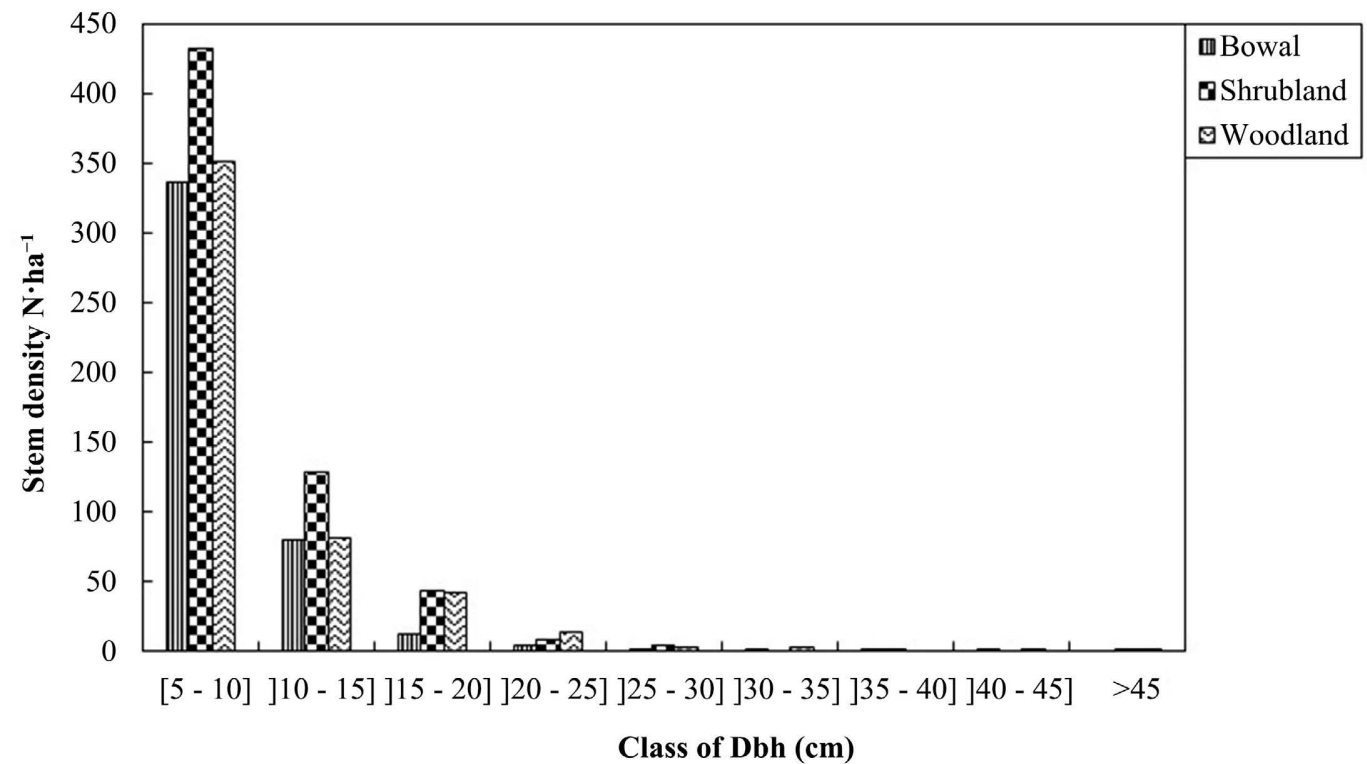

Figure 3. Stem density distribution model as a function of dbh class sampled woody species (except liana) in study area in 2018 . 
Table 3. Linear relationship between AGB $\left(\mathrm{t} \cdot \mathrm{ha}^{-1}\right)$ and density $\left(\mathrm{ha}^{-1}\right)$, AGB and basal area $\left(\mathrm{m}^{2} \cdot \mathrm{ha}^{-1}\right)$ for small- and large-sized trees according to vegetation type.

\begin{tabular}{|c|c|c|c|c|}
\hline \multirow{2}{*}{ Vegetation type } & \multicolumn{2}{|c|}{ Small sized stems $(5 \leq \mathrm{dbh} \leq 10 \mathrm{~cm})$} & \multicolumn{2}{|c|}{ Large sized stems $(\mathrm{dbh}>10 \mathrm{~cm})$} \\
\hline & AGB - Density & AGB - Basal area & AGB - Density & AGB - Basal area \\
\hline \multicolumn{5}{|l|}{ Bowal } \\
\hline Regression equation & $0.48+0.08 x$ & $-1.22+13 x$ & $3.95+0.12 x$ & $0.31+28.0 x$ \\
\hline $\mathrm{R}-\mathrm{Sq}$ & $82.0 \%$ & $14.2 \%$ & $11.8 \%$ & $33.1 \%$ \\
\hline $\mathrm{R}-\mathrm{Sq}$ (adj) & $79.8 \%$ & $3.5 \%$ & $0.0 \%$ & $23.6 \%$ \\
\hline Anova, F & 36.48 & 1.33 & 0.94 & 3.47 \\
\hline$p$-value & $<0.0001$ & 0.28 & 0.37 & 0.11 \\
\hline \multicolumn{5}{|l|}{ Shrubland } \\
\hline Regression equation & $-0.16+0.11 x$ & $5.6-0 x$ & $0.55+0.62 x$ & $-5.05+94.4 x$ \\
\hline $\mathrm{R}-\mathrm{Sq}$ & $91.3 \%$ & $0.0 \%$ & $31.0 \%$ & $76.3 \%$ \\
\hline $\mathrm{R}-\mathrm{Sq}$ (adj) & $90.3 \%$ & $0.0 \%$ & $22.3 \%$ & $73.3 \%$ \\
\hline Anova, F & 84.42 & 0.00 & 3.59 & 25.75 \\
\hline$p$-value & $<0.001$ & 0.999 & 0.095 & 0.001 \\
\hline \multicolumn{5}{|l|}{ Woodland } \\
\hline Regression equation & $0.28+0.10 x$ & $2.51+32.4 x$ & $10.4+0.64 x$ & $19.0+18.2 x$ \\
\hline $\mathrm{R}-\mathrm{Sq}$ & $67.0 \%$ & $1.4 \%$ & $49.6 \%$ & $2.6 \%$ \\
\hline $\mathrm{R}-\mathrm{Sq}$ (adj) & $62.9 \%$ & $0.0 \%$ & $43.3 \%$ & $0.0 \%$ \\
\hline Anova, F & 16.23 & 0.11 & 7.88 & 0.22 \\
\hline$p$-value & 0.004 & 0.75 & 0.02 & 0.65 \\
\hline
\end{tabular}

Regression equation corresponded to AGB $\left(\mathrm{t} \cdot \mathrm{ha}^{-1}\right)=b+a x\left(\right.$ with $x=$ stems $\cdot h \mathrm{~h}^{-1}$ or $x=$ basal area $\left(\mathrm{m}^{2} \cdot \mathrm{ha}^{-1}\right)$.

$50 \%$ of variation observed in AGB were significantly induced by higher density of large sized-stem $(p$-value $=0.02)$.

\section{Discussion}

The present study, done in 3 ha identified 58 species as an evolution of species richness with the number of 1557 recorded plant individuals toward those (67 species) obtained by Nombré (2019). Species richness as well as density of woody plant differs from one vegetation type to another corresponding to the attitude of each species to colonize and establish in one or more vegetation conditions. Woodland was the richest area that exhibits higher species richness and flora (45 species, 36 genera and 14 families) while bowal was the poorest area with lower species richness and composition. But according to the calculated values of Bray-Curtis's index, only shrub- and woodland were different from each other in term of species richness and diversity whereas bowal, shrubland and woodland were similar and formed together homogeneous vegetation. This similarity seems to be linked with the fact that 17 species representing $29.31 \%$ of total species were simultaneously observed on these three vegetation types. Ac- 
cordingly, when we calculate the ratio of species number over stem number (bowal 30/440 $=0.07$; shrubland $35 / 620=0.06$ and woodland $36 / 497=0.09$ ) for each area we obtain a value that tends toward value 0.1 proving that species are evenly distributed between areas. Thoroughly, increase in plant number did not conduct to increase in species richness indicating the (co)-existence of few species represented by many individuals (see Table 1 ) as their response to each vegetation singularity and spatial heterogeneity. It is obvious that vegetation type as canopy layer (with or without soil type) is preponderant in woody species assemblage, density and through the plasticity of some species to colonize and establish in savannah ecosystem (Williams et al., 1996; Oliveira et al., 2017). But the level at which variation occur differ from one to another vegetation type with respect to tree adaptive strategy and performance (Traoré and Jouquet, 2020). Overall results showed pronounced decrease in large stem density and an increase in small trees density across vegetation types. Such habitats may affect the natural regeneration of tree species through the recruitment and the density of vascular undergrowth $(\mathrm{dbh}<5 \mathrm{~cm})$ species and consequently induce heterogeneity in the distribution at small scales. Decrease density of large tree may be the consequence of the absence of positive recruitment in upper sized class due to the negative influence of area that can be observed in many vegetation type (Novor \& Abugre, 2020). In effect, bowal dominated by bare and encrusted soils as ultimate degree of area erosion can further impede the establishment of luxurious woody assemblage. Such, stem density can increase and being limited to the prevalence of small trees resulting from degraded or oppressed site in which plant community is developing strategies that allow them to survive hard conditions but also from a slow growth rate, common in African Sudanian zone (Solbrig, 1994; Zwarg et al., 2012; Padonou et al., 2014) and thereafter influence AGB production.

Significant relationship was found between small tree density and AGB $\left(\mathrm{R}^{2} \geq\right.$ $67 \%)$ in each vegetation type, between larger tree density and AGB $\left(\mathrm{R}^{2}=49.6 \%\right)$ in woodland and between the basal area of larger tree and AGB $\left(\mathrm{R}^{2}=76 \%\right)$ in shrubland. This suggests that distinction in tree dbh class pattern positively and significantly affects $A G B$ as well as vegetation type as bowal, shrubland and woodland with greatest AGB for small trees in bowal. As possible explanation, small individuals related to great AGB may reflect a level of resilience of plant community after disturbance or a great degradation of plant community. In case of restoration post disturbance, plant actively grow through production and differentiations new aerial organs as multiple stems (Zida et al., 2009) in juvenile to tree transition and become established as adult trees. Our results agree with previous studies carried out in dry and humid environments (Oliveira et al., 2017; Astri et al., 2020). Oliveira et al. (2017) had indicated that in forest and non-forest environments, more individuals are distributed in the minor diameter classes while few individuals are found in the major diameter classes and Astri et al. (2020) reported that small sized trees were positively connected with great AGB in savannah system. But, according to these last authors, the contri- 
butions of small sized trees to basal area and stem density were significantly different between vegetation types. Therefore, attention may be paid to the horizontal structure in communities and bowal contribution for management and restoration monitoring since our analyses also pointed out a decline in vascular vegetation layer.

\section{Conclusion}

We have assessed woody community related to the functioning of ecosystems through stand density and size structure of woody species and AGB through three vegetation types as bowal, shrubland and woodland. Results revealed similarity between them for species diversity and composition while significant difference was underlined in stand abundance with small tree predominance. We found that the positive variation in plant community structure was generated by the positive relationship between stem size and produced AGB. Such, increase density in small sized stem in community result from increase accumulated aboveground biomass as positive regeneration features, but positive stem recruitment in upper diameter class was hindered as the higher degree of vegetation degradation. The results illustrate the importance of including stand structure in total AGB estimation for plant community. Therefore, we suggest considering stem size to be used to discriminate AGB level and vegetation conditions in regeneration monitoring regarding species composition. And then, measures could be taken to adapt co-management of natural vegetation and reinforce ecosystem services and goods production.

\section{Acknowledgements}

Current study did not obtain any external financial support. Authors grateful to the staff of "Direction provincial des Eaux et Forêts, Houet" for authorizing us to work and ensuring our security in Dindéresso forest and Dr Djibril S. Dayamba for valuable suggestions. Special thanks to the staff of IRD-Bobo for allowing us to access institute e-library and to the two anonymous reviewers for their valuables comments and suggestions.

\section{Data Availability Statement}

All data supporting the results of our study are available from the corresponding author on decent demand.

\section{Conflicts of Interest}

Authors state that no conflict of interest exists for this article.

\section{References}

Adjahossou, S. G. C., Gouwakinnou, G. N., Houehanou, D. T., Sode, A. I., Yaoitcha, A. S., Houinato, M., \& Sinsin, B. (2017). Efficacité des aires protégées dans la conservation d'habitats favorables prioritaires de ligneux de valeur au Bénin. Bois \& Forêts des Tropiques, 328, 67-76. https://doi.org/10.19182/bft2016.328.a31303 
Arbonnier, M. (2000). Arbres, arbustes et lianes des zones sèches de l'Afrique de l'Ouest. CIRAD, MNHN, UICN.

Atsri, H. K., Kokou, K., Abotsi, K. E., Kokutse, A. D., \& Cuni-Sanchez, A. (2020). Above-Ground Biomass and Vegetation Attributes in the Forest-Savannah Mosaic of Togo, West Africa. African Journal of Ecology, 58, 733-745. https://doi.org/10.1111/aje.12758

Attua, E. M., Awanyo, L., \& Antwi, E. K. (2017). Effects of Anthropogenic Disturbance on Tree Population Structure and Diversity of a Rain Forest Biosphere Reserve in Ghana, West Africa. African Journal of Ecology, 56, 116-127. https://doi.org/10.1111/aje.12427

Bahiré, F. X. W. (2016). Étude diachronique des changements du couvert végétal dans les écosystèmes forestiers par télédétection spatiale et par suivi au sol: Cas de la forêt classée de Dindéresso Burkina Faso. ENEF/Dindéresso.

Balima, L. H., Nacoulma, B. M. I., Bayen, P., Dimobé, K., N’Guessan, K. F., \& Thiombiano, A. (2019). Aboveground Biomass Allometric Equations and Distribution of Carbon Stocks of the African Oak (Afzelia africana Sm.) in Burkina Faso. Journal of Forest Research, 31, 1699-1711. https://doi.org/10.1007/s11676-019-00955-4

Chave, J., Coomes, D., Jansen, S., Lewis, S. L., Swenson, N. G., \& Zanne, A. E. (2009). Towards a Worldwide Wood Economics Spectrum. Ecology Letters, 12, 351-366. https://doi.org/10.1111/j.1461-0248.2009.01285.x

Chave, J., Rejou, M. M., Burquez, A., Chidumayo, E., Colgan, M. S., Delitti, W. B. C., Duque, A., Eid, T., Fearnside, P. M., Goodman, R. C., Henry, M., Martinez-Yrizar, A., Mugasha, W. A., Muller-Landau, H. C., Mencuccini, M., Nelson, B. W., Ngomanda, A., Nogueira, E. M., Ortiz-Malavassi, E., Pelissier, R., Ploton, P., Ryan, C. M., Saldarriaga, J. G., \& Vieilledent, G. (2014). Improved Allometric Models to Estimate the Above-Ground Biomass of Tropical Trees. Global Change Biology, 20, 3177-3190.

https://doi.org/10.1111/gcb.12629

Colwel, R. K. (2013). EstimateS: Statistical Estimation of Species Richness and Shared Species from Samples. Version 9.1. Persistence.

http://viceroy.eeb.uconn.edu/EstimateS/EstimateSPages/EstSUsersGuide/EstimateSUse rsGuide.htm

Coomes, D. A., \& Allen, R. B. (2007). Effects of Size, Competition and Altitude on Tree Growth. Journal of Ecology, 95, 1084-1097.

https://doi.org/10.1111/j.1365-2745.2007.01280.x

Damena, E. D., \& Teshome, S. (2019). Allometric Equations for Aboveground Biomass Estimation of Diospyros abyssinica (Hiern) F. White Tree Species, Ecosystem. Health and Sustainability, 5, 86-97. https://doi.org/10.1080/20964129.2019.1591169

Dayamba, S. D., Djoudi, H., Zida, M., Sawadogo, L., \& Verchot, L. (2016). Biodiversity and Carbon Stocks in Different Land Use Types in the Sudanian Zone of Burkina Faso, West Africa. Agriculture, Ecosystems and Environment, 216, 61-72. https://doi.org/10.1016/j.agee.2015.09.023

Driessen, P., Deckers, J., \& Spaargaren, O. (2001). Lecture Notes on the Major Soils of the World. Food and Agriculture Organization of the United Nations.

Fontes, J., \& Guinko, S. (1995). Carte de la végétation et de l'occupation du sol du Burkina Faso/Notice explicative. Laboratoire d'Ecologie Terrestre, Institut de la Carte Internationale de la Végétation. CNRS, Université de Toulouse III (France)/Institut du Développement Rural, Faculté des Sciences et Techniques, Université de Ouagadougou (Burkina Faso).

Ganamé, M., Bayen, P., Ouédraogo, I., Dimobe, K., \& Thiombiano, A. (2019). Woody Species Composition, Diversity and Vegetation Structure of Two Protected Areas along 
a Climatic Gradient in Burkina Faso (West Africa). Folia Geobotanica, 54, 163-175. https://doi.org/10.1007/s12224-019-09340-9

Gebrewahid, Y., Gebre-Egziabhier, T. B., Teka, K., \& Birhane, E. (2018). Carbon Stock Potential of Scattered Trees on Farmland along an Altitudinal Gradient in Tigray, Northern Ethiopia. Ecological Processes, 7, 40. https://doi.org/10.1186/s13717-018-0152-6

Higgins, S. I., William, J., Bond, W. I., February, E. C., Bronn, A., Douglas, I. W., Euston-Brown, D. I. W., Enslin, B., Govender, N., Rademan, L., O’regan, S., Potgieter, A. L. F., Scheiter, S., Sowry, R., Trollope, L., \& Trollope, W. S. W. (2007). Effects of Four Decades of Fire Manipulation on Woody Vegetation Structure in Savanna. Ecology, 88, 1119-1125. https://doi.org/10.1890/06-1664

Holl, K. D., \& Zahawi, R. A. (2014). Factors Explaining Variability in Woody Above-Ground Biomass Accumulation in Restored Tropical Forest. Forest Ecology and Management, 319, 36-43. https://doi.org/10.1016/j.foreco.2014.01.024

Holmgren, M., Poorter, L., \& Siepel, A. (2004). Ch. 7: What Explains the Distribution of Rare and Endemic West African Plants? In L. Poorter, F. Bongers, F. Y. N. Kouamé, \& W. D. Hawthorne (Eds.), Biodiversity of West African Forests: An Ecological Atlas of Woody Plant Species (pp. 73-85). CAB International, Wallingford. https://doi.org/10.1079/9780851997346.0073

Hooper, D. U., Chapin, III F. S., Ewel, J. J., Hector, A., Inchausti, P., Lavorel S., Lawton, J. H., Lodge, D. M., Loreau, M., Naeem, S., Schmid, B., Setälä, H., Symstad, A. J., Vandermeer, J., \& Wardle, D. A. (2005). Effects of Biodiversity on Ecosystem Functioning: A Consensus of Current Knowledge. Ecological Monographs, 75, 3-35. https://doi.org/10.1890/04-0922

IPNI (2021, July 29). International Plant Names Index. http://www.ipni.org

IUCN (2021, July 29). The IUCN Red List of Threatened Species. Version 2020-2. https://www.iucnredlist.org

Kadéba, A., Sambaré, O., Soulama, S., Thiombiano, A., Schmidt, M., \& Boussim, J. I. (2014). Typologie spatiale de la végétation sahélienne en relation avec les indicateurs de dégradation au Burkina Faso. International Journal of Biology and Chemical Sciences, 8, 1049-1064. https://doi.org/10.4314/ijbcs.v8i3.19

Kéita, I. (2019). Impact des termitières épigées sur la dynamique et la régénération de la végétation ligneuse dans la forêt classée de Dinderesso, Burkina Faso. Master Thesis, Department of Sciences Biologiques, Université Nazi Boni.

Kindt, R., \& Coe, R. (2005). Tree Diversity Analysis. A Manual and Software for Common Statistical Methods and Biodiversity Studies. World Agroforestry Centre.

Krebs, C. J. (1972). Ecology: The Experimental Analysis of Distribution and Abundance. Harper International.

Kuma, M., \& Shibru, S. (2015). Floristic Composition, Vegetation Structure, and Regeneration Status of Woody Plant Species of Oda Forest of Humbo Carbon Project, Wolaita, Ethiopia. Journal of Botany, 2015, Article ID: 963816. https://doi.org/10.1155/2015/963816

Lorenz, K., \& Lal, R. (2010). Ch. 3: Effects of Disturbance, Succession and Management on Carbon Sequestration. In Carbon Sequestration in Forest Ecosystems (pp. 103-146). Springer. https://doi.org/10.1007/978-90-481-3266-9_3

Manaye, A., Tesfamariam, B., Tesfaye, M., Worku, A., \& Gufi, Y. (2021). Tree Diversity and Carbon Stocks in Agroforestry Systems in Northern Ethiopia. Carbon Balance Management, 16, 14. https://doi.org/10.1186/s13021-021-00174-7

Matula, R., Damborská, L., Nečasová, M., Geršl, M., \& Šrámek, M. (2015). Measuring 
Biomass and Carbon Stock in Resprouting Woody Plants. PLoS ONE, 10, e0118388. https://doi.org/10.1371/journal.pone.0118388

Mbow, C., Verstraete, M. M., Sambou, B., Diaw, A. T., \& Neufeldt, H. (2014). Allometric Models for Aboveground Biomass in Dry Savanna Trees of the Sudan and Sudan-Guinean Ecosystems of Southern Senegal. Journal of Forest Research, 19, 340-347. https://doi.org/10.1007/s10310-013-0414-1

Murphy, B. P., Cochrane, M. A., \& Russell-Smith, J. (2015). Prescribed Burning Protects Endangered Tropical Heathlands of the Arnhem Plateau, Northern Australia. Journal of Applied Ecology, 52, 980-991. https://doi.org/10.1111/1365-2664.12455

Nombré, S. A. H. (2019). Etude de la dynamique et de l'état de régénération de Prosopis africana (guill., perrott. et rich.) Taub. dans la forêt classée de Dinderesso, Burkina Faso. Master Thesis, Department of Biological Sciences, Université Nazi Boni.

Novor, S., \& Abugre, S. (2020). Growth Performance, Undergrowth Diversity and Carbon Sequestration Potentials of Tree Species Stand Combinations, Ghana. Open Journal of Forestry, 10, 135-154. https://doi.org/10.4236/ojf.2020.101010

Oliveira, R., Farias, H., Perdiz, R., Scudeller, V., \& Imbrozio Barbosa, R. (2017). Structure and Tree Species Composition in Different Habitats of Savanna Used by Indigenous People in the Northern Brazilian Amazon. Biodiversity Data Journal, 5, e20044. https://doi.org/10.3897/BDJ.5.e20044

Padonou, E., A., Adomou, A. C., Bachmann, Y., Lykke, A. M., \& Sinsin, B. (2014). Vegetation Characteristics of Bowé in Benin (West Africa). Journal of Plant Sciences, 2, 250-255. https://doi.org/10.11648/j.jps.20140205.27

Pearson, T., Walker, S., \& Brown, S. (2005). Sourcebook for Land Use, Land-Use Change and Forestry Projects. Winrock International and the BioCarbon.

Rakotomavo, A., Rasoamanarivo, R., \& Razanajaza, P. (2018). Impact of Urban Anthropogenic Pressures on the Mangrove Forest of Sainte Marie (East Madagascar). Open Journal of Forestry, 8, 380-392. https://doi.org/10.4236/ojf.2018.83024

Sawadogo, L., Tiveau, D., \& Nygård, R. (2005). Influence of Selective Tree Cutting, Livestock and Prescribed Fire on Herbaceous Biomass in the Savannah Woodlands of Burkina Faso, West Africa. Agriculture, Ecosystems and Environment, 105, 335-345. https://doi.org/10.1016/j.agee.2004.02.004

Solbrig, O. T. (1994). Plant Traits and Adaptive Strategies: Their Role in Ecosystem Function. In S. Ernst-Detlef, \& H. A. Mooney (Eds.), Biodiversity and Savanna Ecosystem Processes: A Global Perspective (Ecological Studies, Vol. 121) (pp. 97-116). Springer-Verlag. https://doi.org/10.1007/978-3-642-58001-7_5

Traoré, S., \& Jouquet, P. (2020). Growth Performance and Adaptive Strategy of Early Seedlings of Three Savanna Woody Species in Pots as Feedback to the Soil of Macrotermes subhyalinus Mound. European Scientific Journal, 16, 1. https://doi.org/10.19044/esj.2020.v16n3p1

Traoré, S., Tigabu, M., Jouquet, P., Ouédraogo, S. J., Guinko, S., \& Lepage, M. (2015). Long-Term Effects of Macrotermes Termites, Herbivores and Annual Early Fire on Woody Undergrowth Community in Sudanian Woodland, Burkina Faso. Flora, 211, 40-50. https://doi.org/10.1016/j.flora.2014.12.004

Weiber, J. A., \& Grulke, N. E. (1995). Ch. 14. Response of Stem Growth and Function to Air Pollution. In B. L. Gartner (Ed.), Plant Stems: Physiology and Functional Morphology (pp. 343-363). Academic Press.

https://doi.org/10.1016/B978-012276460-8/50017-5

White, F. (1983). The Vegetation of Africa, a Descriptive Memoir to Accompany the 
UNESCO/AETFAT/UNSO Vegetation Map of Africa. UNESCO. Natural Resources Research.

Williams, R. J., Duff, G. A., Bowman, D. M. J. S., \& Cook, G. D. (1996). Variation in the Composition and Structure of Tropical Savannas as a Function of Rainfall and Soil Texture along a Large-Scale Climatic Gradient in the Northern Territory, Australia. Journal of Biogeography, 23, 747-756. https://doi.org/10.1111/j.1365-2699.1996.tb00036.x

Zanne, A. E., Lopez-Gonzalez, G., Coomes, D. A., Ilic, J., Jansen, S., Lewis, S. L., Miller, R. B., Swenson, N. G., Wiemann, M. C., \& Chave, J. (2009). Towards a Worldwide Wood Economics Spectrum, Dryad, Dataset. https://doi.org/10.5061/dryad.234

Zar, J. H. (1999). Biostatistical Analysis (4th ed.). Prentice Hall International, Inc.

Zida, D., Tigabu, M., Sawadogo, L., Tiveau, D., \& Odén, P. C. (2009). Long-Term Effects of Prescribed Early Fire, Grazing and Selective Tree Cutting on Seedling Populations in the Sudanian Savanna of Burkina Faso. African Journal of Ecology, 47, 97-108. https://doi.org/10.1111/j.1365-2028.2008.01011.x

Zwarg, A., Schmidt, M., Janßen, T., Hahn, K., \& Zizka, G. (2012). Plant Diversity, Functional Traits and Soil Conditions of Grass Savannas on Lateritic Crusts (bowé) in South Eastern Burkina Faso. Flora et Vegetatio Sudano-Sambesica, 15, 15-24.

https://doi.org/10.21248/fvss.15.18 